\title{
The Larkin Papers
}

年 



\section{THE}

Larkin Papers

Personal, Business, and Official Correspondence of Thomas Oliver Larkin, Merchant and United States Consul in California $\odot$ Edited by George P. Hammond, Director of the Bancroft Library -

INDEX

ANNA MARIE HAGER and EVERE'TT G. HAGER

Published for the Bancroft Library by the

UNIVERSITY OF CALIFORNIA PRESS BERKELEY AND LOS ANGELES

1968 
UNIVERSITY OF CALIFORNIA PRESS

BERKELEY AND LOS ANGELES, CALIFORNIA

$\diamond$

CAMBRIDGE UNIVERSITY PRESS

LONDON, ENGLAND

COPYRIGHT (1) 1968, BY

THE REGENTS OF THE UNIVERSITY OF CALIFORNIA

LIBRARY OF CONGRESS CATALOG CARD NUMBER: $52-735^{8}$ 